\title{
KAJIAN ISLAM TERHADAP PROBLEM POLITIK UANG DALAM PILKADA DI INDONESIA
}

\author{
Abdul Wahid \\ Program Studi Ilmu Hukum Universitas Islam Malang
}

\begin{abstract}
It's not only the citizen (constituent) who determines the image of mayor election (Pilkada) but also anybody who influences the citizen in order to gain the support from people has big influence through the image of democracy. One of political bad habits and law deviations which blot the image of mayor election (Pilkada) is money politics. It's the time for each people to not mortgage the democracy through money politics, since money politics can only make the future of country becomes even worse as a nonethics country. In the Islamic doctrine, money politics can be categorized as bribing practice or a forbidden activity
\end{abstract}

Keywords: money politics, bribing practice, democracy, Islam, mayor election

\section{PENDAHULUAN}

Upaya membangun kehidupan bangsa dan negara yang berlandaskan moral dan agama ternyata tidak gampang. Kalangan pemeluk agama tidak selalu menjalankan agamanya dengan jujur dan konsekuen. Tidak sedikit ditemukan sikap dan perilaku anggota masyarakat yang berlawanan dengan norma agama yang dipeluknya.

Sikap dan perilaku masyarakat yang bercorak paradoksal dengan norma agama itu bukan hanya dilakukan oleh seseorang atau warga yang tidak berpendidikan tinggi, tetapi juga kalangan terdidik, bergelar, atau elit sosial-politik yang menyandang status sebagai tokoh agama. Mereka tergelincir memburu kedudukan mapan di lingkaran kekuasaan dengan menghalalkan segala cara, yang salah satu caranya dengan menggunakan uang.

"Jika seseorang memiliki satu sen uang, maka dia berkuasa sejauh satu sen atas manusia", demikian ungkap Daniel Duncan, yang ditujukan sebagai kritik keras terhadap setiap orang yang punya kekuasaan atau berobsesi merebut kekuasaan yang menjadikan uang sebagai alat utamanya. (Munawar, 2009)

Duncan sangat geram terhadap seseorang atau sekelompok orang dalam komunitas politik yang bermaksud menggunakan uang sebagai senjata utama untuk memenangkan pertarungan dalam merengkuh kekuasaan. Dalam penilaiannya, uang digunakan dengan cara demikian bukan hanya akan menutup pintu persaingan yang sehat, cerdas, dan berhati nurani, tetapi mampu menempatkan kesejatian dirimanusia dibawah kekuasaan uang.

This work is licensed under Creative Commons Attribution Non Commercial 4.0 International License Available online on: http://riset.unisma.ac.id/index.php/natiq/index 


\section{MEMBACA PETUALANG POLITIK}

Uang memang merupakan alat tukar yang mampu menukar kepribadian seseorang. Dari uang yang dimiliki seseorang, apalagi elit kekuasaan, ia bisa menggunakannya untuk membelokkan jalan hidup orang lain. (Ahmad, 2009). Sebenarnya bukan hanya Duncan yang geram menyaksikan perilaku seseorang atau petualang-petualang politik yang menggunakan uang sebagai alat menghancurkan integritas moral masyarakat, tetapi unsur-unsur bangsa beradab, beretika, dan beragama dimanapun adanya pasti tidak menyetujui uang diperlakukan sebagai alat kotor yang mengotori praktik-praktik suci kehidupan ketatanegaraan.

Menjadi kondisi yang dipahami publik, terjun dalam arena politik membutuhkan modal yang cukup banyak seperti diantaranya harus cerdas, kredibel, akuntabel, punya jaringan yang luas, dan punya uang banyak. Namun demikian, yang terakhir (uang) selalu menjadi problem tersendiri terutama bagi mereka yang baru terjun dalam dunia politik praktis dan tidak mempunyai cukup resources untuk itu. (Faqthuri, 2010)

Uang dan politik ibarat makanan (nasi) dan lauk, keduanya harus selalu seiring dan seirama. Nasi tanpa lauk yang menyertainya hanya akan membuat makan tidak berasa. Begitupun terjun dalam dunia politik praktis tanpa mempunyai uang hanya akan membuat imajinasi kekuasaan semakin menjauh. Hal ini berarti bahwa, bagi mereka yang ingin terjun dalam dunia politik, mereka harus mempunyai uang yang cukup sebab uang adalah salah satu faktor determinan untuk bisa maju dalam kancah politik (Faqthuri, 2010). Mereka yang terjun ke dunia politik tanpa memiliki uang banyak, dalam realitasnya sekarang, berakhir sia-sia. Sedangkan tidak sedikit ditemukan seseorang yang terpilih menduduki jabatan tertentu yang berbekal uang banyak untuk memenangkannya, yang mengalami nasib memprihatinkan seperti berurusan dengan aparat penegak hukum akibat uang yang digunakan, ternyata diperoleh dengan cara-cara yang melanggar norma hukum. (Walhid, 2010)

Pemilihan kepala daerah secara langsung (pilkada) mempunyai nilai signifkan dalam pembangunan demokrasi yang sehat dan dinamis. Demokrasi yang sehat harus di pahami sebagai sebuah proses menuju masyarakat yang lebih cerdas, mandiri dan bermartabat. Pilkada adalah momentum untuk membangun kesadaran guna melahirkan insan-insan yang berjiwa rasional, jujur, anti KKN (kolusi, korupsi, nepotisme) dan bertanggung jawab serta tidak melakukan berbagai bentuk penipuan terhadap rakyat dalam bentuk apapun. Namun perlu disadari bersama bahwa demokrasi lokal (pilkada) tidak selamanya akan melahirkan insan-insan tersebut di atas, bahkan bisa jadi demokrasi tersebut penuh dengan berbagai kecurangan dan rekayasa manipulatif. (Jannah, 2005)

Kasus kecurangan dalam Pilgub Jawa Timur yang pernah diperiksa oleh Mahkamah Konstitusi (MK) RI, adalah salah satu contoh kasus yang dapat dijadikan pelajaran riil, bahwa praktik politik uang ikut mewarmai penyelenggaran demokrasi di daerah. Kehadiran MK telah memberikan angin segar bagi pencari 
keadilan atau calon-calon yang kecurangan menjadi korban penyelenggaraan demokrasi di daerah.

Pergulatan politik seringkali menjadi ajang perebutan kekuasaan yang terkadang tidak berbanding lurus dengan lahirnya masyarakat yang lebih sejahtera. Realitasnya masyarakat masih sangat miskin dari segi pendidikan. Sehingga ketika datangnya momentum politik seperti demokrasi lokal ini sebagian masyarakat merasa bahwa demokrasi telah sampai pada titik nadir yang membosankan dan tidak mampu mengangkat sisi kesejahteraan mereka. Wajar saja bila masyarakat mulai apatis terhadap persolan-persolan politik karena selama ini corak berpolitik kaum elit politik dalam ragam kepentingan di negeri ini masih belum bergeser kepada corak berpolitik yang lebih mencerdaskan dan menyentuh kebutuhan asasi masyarakat (Jannah, 2005). Berpolitik gaya elitis masih tefokus pada "kepentingan perut sendiri dan kroni". Mereka terkadang seperti berkelahi atau berkonflik, padahal dibalik itu, mereka sebelumnya sudah saling mengerti. (Munawar, 2009)

Demokrasi lokal (pilkada) tersebut akan menyentuh seluruh lapisan sosial di masyarakat. Berbagai asumsi mengenai persoalan pilkada yang ideal muncul dalam berbagai diskusi biasa sampai kepada diskusi yang formal, wajar saja misalnya kalau ada yang beranggapan bahwa pilkada dikhawatirkan munculnya berbagai tindakan kecurangan atau kekerasan serta meningkatnya jumlah suara yang golput. Sebab faktanya dibeberapa daerah di tanah air pilkada diwarnai dengan berbagai kecurangan berupa politik uang, kekerasan masa, serta prilaku yang dapat menghambat proses kelancaran pilkada. (Jannah, 2005)

\section{OPSI POLITIK UANG}

Di berbagai daerah yang melaksanakan pesta demokrasi lokal tersebut banyak menuai persoalan, salah satunya adalah persoalan politik uang yang dilakukan oleh elit politik guna membeli suara masyarakat. Fenomena politik uang (money politic) mewarnai berbagai even pilkada di tanah air. Hal ini tentu menjadi gambaran bahwa tingkat kecurangan dalam melaksanakan pilkada tersebut sangat tinggi. Namun tentu saja untuk memahami dan mengurai benang kusut persoalan tersebut, yang dilakukan oleh elit politik, masyarakat perlu mendapat informasi yang akurat tentang praktek politik uang serta perangkat peraturannya. Sebab jika memperhatikan fenomena ini tentu kita perlu menganalisis kecenderungan elit politik dan masyarakat dalam memahami hakikat dari demokrasi lokal tersebut. (Jannah, 2005)

Sebagian besar rakyat telah terbiasa dengan praktik (politik uang) ini dalam proses-proses politik yang terjadi yang dilakukan secara langsung, baik untuk memilih kepala desa, bupati/wakil bupati, walikota/wakil walikota, maupun gubernur/wakil gubernur. Padahal, salah satu pertimbangan dilakukannya pemilihan langsung adalah praktik politik uang bisa diminimalisir. Bahkan dalam demokrasi langsung sebagaimana yang teriadi selama ini, praktik politik uang menjadi semakin tak dapat dikendalikan. Berbagai peraturan perundang undangan 
yang nmelarang praktik haram ini, seolah dibuat hanya untuk melanggar. (ElManaf, 2008)

Praktik politik uang dalam setiap perhelatan politik tersebutlah yang kemudian menyebabkan masyarakat tidak bisa membedakan antara penyelenggaraan mekanisme politik dengan politik uang. Singkatnya, terbangun pandangan umum bahwa politik uang dalam setiap kompetisi politik adalah sebuah keharusan. Inilah agar kemudian yang menyebabkan semacam pandangan bahwa seolan terdapat empat faktor dalam proses kompetisi politik, yaitu: uang (El- Manaf, 2008). Uang telah dijadikan sebagai tujuan, sehingga terbentuk menjadi "tuhan kontemporer". yang sangat berpengaruh (Faisol, 2009)

Selain itu, partai politik tidak siap menyediakan kader-kader handal, baik sebagai calon maupun sebagai relawan yang mau bekerja secara militan untuk mensosialisasikan calon-calon yang diajukan oleh partai. Dengan demikian, calon. yang maju kemudian melakukan cara-cara instan dan praktis untuk menggerakkan rakyat yang memiliki hak pemilih untuk memberikan hak calon pilihnya. (Fatwa, 2008)

Hal inilah yang kemudian menyebabkan kualitas pejabat publik menjadi terabaikan. Sebab, seseorang dipilih menjadi pejabat politik bukan karena kualitas atau kapasitasnya dan kompetensinya untuk menempati posisi politik tersebut, tetapi semata-mata karena memberikan uang kepada para pemilih menjelang saat pemilihan. Inilah menyebabkan jabatan-jabatan publik akhimya ditempati oleh kaum medioker alias mereka yag sesungguhnya tidak memiliki prestasi memadai untuk menjalankan struktur negara. Akibatnya tentu saja struktur negara tidak akan bekerja dengan baik untuk mewujudkan cita-cita negara untuk mewujudkan kebaikan bersama (common goods). (Fatwa, 2008)

\section{PENODAAN DEMOKRASI}

Demokrasi dalam arti sebenarnya terkait dengan pemenuhan hak asasi manusia. Dengan demikian ia merupakan fitrah yang harus dikelola agar menghasilkan output yang baik. Setiap manusia memiliki hak untuk menyampaikan pendapat, bermasyarakat. Dengan demikian, demokrasi pada dasarnya memerlukan aturan main. Aturan main tersebut sesuai dengan nilai-nilai Islam dan sekaligus yang terdapat dalam undang-undang maupun peraturan pemerintah. Di masa transisi, sebagian besar orang hanya tahu mereka bebas berbicara, beraspirasi, berdemonstrasi. Namun aspirasi yang tidak sampai akan menimbulkan kerusakan. Tidak sedikit fakta yang memperlihatkan adanya pengrusakan ketika terjadinya demonstrasi menyampaikan pendapat. Untuk itu orang memerlukan pemahaman yang utuh agar mereka bisa menikmati demokrasi. (Prayitno, 2010). Upaya menikmati demokrasi ini diantaranya, seharusnya berkumpul, berserikat dan bisa melalui Pilkada. Karena dalam Pilkada ini, pesta pelibatan rakyat benar-benar diwujudkan.

Kalau sudah begitu, pesta demokrasi, meski itu berupa Pilkada secara langsung yang disebut representasi demokrasi berbasis kerakyatan, sulit atau 
mustahil bisa mencerminkan pesta suci yang menjalankan, menghidupkan dan memberdayakan pendidikan demokrasi (democratic education), karena pola kompetisinya sudah dikendalikan oleh "mesin uang". Kalau itu memang benarbenar diarahkan demi pendidikan demokrasi, tentulah setiap penyelenggara menunjukkan kinerja maksimalnya untuk membangun partisipasi masyarakat. (Faisol, 2009)

Demokrasi diserang dari segala lini, kelompok ekstrimis agama, pembisnis menyerang demokrasi dengan gencar. Di mana demokrasi, diserang oleh kelompok ekstrimis agama melalui kekerasan. sementara itu, pembisnis menyerang melalui uang. (http://www.indonesiamenulis.com/ 2009/05/politik-uang-danmarginalisasi- demokrasi.html)

George Walker Bush mengumpulkan 37 juta dollar, lebih besar daripada yang dikumpulkan Bill Clinton atau Bob Dole selama kampanye 1996. John Corzine, mantan direktur Goldman Sachs, mengeluarkan 36 juta dollar dari kantongnya sendiri untuk merebut kursi senat. Kandidat yang kalah, Michael Huffington, mengeluarkan sebanyak 30 juta dollar ketika berusaha mendapatkan kursi Senate di California. Sementara itu, Kamis 6 Sep 2007, Chung Mong-Koo (Dedengkot Group otomotif Hyundai dari Kor-Sel) dijatuhi hukuman 3 th penjara oleh pengadilan tinggi Seoul. Chung diajukan ke pangadilan karena meyediakan dana khusus bernilaijutaan Dollar AS u/ menyuap aparat Pemerintah, Politisi, dan Bankir demi keperluan perusaliaan yang dipimpin oleh Chung tsb. Suap menyuap atau politik uang telah menjadi kekuatan terselubung, yang justru sangat menentukan, bukan hanya dalam level regional, tetapi juga global. (http:/ /www.indonesiamenulis.com/2009/05/politik-uang- dan-marginalisasidemokrasi.html)

Hampir di semua negara dunia, dari Paris sampai Moskwa, dari London hingga Washinton, perusahaan dan pebisnis mendanai para politisi dan partai politik. DiAmerika, misalnya, hanya $1 / 4$ dari satu persen populasi memberikan 200 dollar atau lebih dari itu kepada kandidat anggota kongres atau partai-partai politik pada putaran pemilihan 1995- 1996 dan 96 persen rakyat Amerika tidak memberikan uang sepeserpun kepada politisi atau partai pada tingkat federal. 500 perusahaan terbesar Amerika, di sisi lain, memberikan 260 juta dollar pada para kandidat Partai Demokrat dan Partai Republik dari 1987 sampai 1996. (http://www.indonesiamenulis.com/2009/05/politik-uang-danmarginalisasidemokrasi.html)

Tidak bisa dipungkiri lagi, dalam ranah politik, uang merupakan faktor yang sangat penting Uang bisa memberikan pengaruh yang sangat signifikan bagi terbentuknya keseimbangan demokrasi. Namun uang juga bisa menjadi bencana manakala pemanfaatannya tidak didasarkan pada aturan legal-formal dan cenderung untuk mendanai aktifias-akifitas illegal. Dalam kontek yang demikian, uang acapkali menjadi alat membeli suara (money politics) atau sebagai alat jualbelijabatan yang dilakukan oleh beberapa oknum untuk mengejar kepentingan politik sesaat. Kenyataan di Indonesia menunjukkan bahwa bagi mereka yang 
mempunyai uang banyak, uang seringkali menjadi alat untuk mencapai kekuasaan sementara bagi mereka yang tidak berduit, mereka akan menghalalkan segala cara untuk mendapatkan uang tersebut. (Faqthuri, 2010)

Rakyat tidak akan mendapatkan sosok yang mumpuni ketika kandidat bupati atau walikota misalnya dibiarkan saja menghalalkan pertarungan yang memperlakukan dirinya dalam kapitalisme politik Dalam ranah demikian, rakyat akhirnya semakin menyempitkan makna politik identik dengan kursi yang memediasi memgalir derasnya uang. Rakyat diperangkap dan mengikuti pembenaran aborsi pendidikan demokrasi yang digerilyakan secara massif oleh oportunis-oportunis politik. Akibatnya, rakyat mustahil bisa membaca dengan cerdas obyektifitas kandidat yang hendak dipilih. Nurani rakyar tidak lagi bening karena kuatnya hegemoni uang mengaburkan kecerdasannya.

Sementara itu, ketika nantinya (paska terpilih dan menjalankan roda pemerintahan) ada bupati-wabup atau walikota-wawalikota, yang berurusan dengan hukum karena melakukan korupsi kekuasaan, maka kesalalhan dapat dilacak sejak Pilkada berlangsung.

Dalam pilkada yang membuat masing- masing kandidat harus dan terpaksa menguras uangnya, tentulalh ketika berhasil menduduki kursi, pimpinan daerah ini potensial bereksperimen memanfaatkan kekuasaanya untuk melunasi utangutang atau menutup pengeluarnya dulu (ketik pilkada). Mereka benar-benar membuktikan ajaran Lord Acton kalau "kekuasaan itu cenderung untuk korupsi". (Faisol, 2009)

Mao Tze Tung pernah bilang bahwa "dengan bedil, kekuasaan bisa direbut," uang banyak, kekuasaan pun bisa direbut, karena "kekuasaan uang" bisa digunakan untuk membeli banyak bedil, dan dari bedil bisa diarahkan untuk menembak jatuh penguasa yang sedang duduk manis di piramida kekuasaannya. Hal ini menunjukkan bahwa money is power. Apa ini nantinya yang akan benarbenar terbukti?

Dengan Tidak bisa dipungkiri, uang memegang peranan penting dalam proses-proses politik. Bagaimana tidak, seseorang yang tadinya tidak populer dan tidak punya kapasitas dan kredibilitas bisa dengan mudah menggapai kekuasaan yang diperebutkan banyak orang hanya dengan benda yang bernama uang. Bagi mereka yang mempunyai uang, mereka tidak akan terlampau sulit untuk bisa mempengaruhi masyarakat pemilih dengan beragam cara seperti pemanfaatan media (iklan, siaran radio dan semacamnya) untuk membangun citra diri dan mensosialisasikan visi dan misi mereka. Pada saat yang sama, bagi mereka yang tidak punya uang, ruang gerak mereka akan dengan sendirinya terbatas sehingga kesempatan untuk memenang pertarungan semakin susah meskipun pentig dicatat di sini bahwa tidak ada garansi orang yang mempunyai uang banyak akan selalu menang dalam pertarungan perebutan kekuasaan (Faqthuri, 2010 Politik uang akhirnya menjadi kekuatan yang mampu merusak dan menghancurkan pendidikan demokrasi. (Munawar, 2009) 
Oleh karena tidak ada garansi sebagai pemenang, banyak orang kerapkali menggunakan jalan pintas untuk menggapai kekuasaan dengan melakukan praktek-praktek kotor seperti yang kita kenal dengan sebutan "money politics". Semua mafhum, di Indonesia fenomena politik uang masih dan terus menggejala sedemikian akut bak jamur di musim hujan sehingga ritme permainan politik sangat susah untuk dijauhkan dari praktek-praktek politik uang. Meskipun tidak bisa dinafikan, produk undang-undang termasuk perangkat sistem pengawasan terhadap praktek-praktek "money politics" sudah dibentuk, namun pada kenyataannya, praktek "money politics" masih sangat susah untuk dibendung. Agaknya fenomena ini masih tetap menjadi "trend" yang selalu menghiasi wajah perpolitikan Indonesia baik di tingkat nasional maupun lokal (Faqthuri, 2010). Kekuatan politik uang seperti "hantu" yang bisa masuk ke berbagai lapisan masyarakat. Kekuatan politik uang bukan sekedar tapi mempengaruhi, mencengkeram, masyarakat. (Faisol, 2009)

Kita acapkali mendengar dan membaca informasi tentang maraknya politik uang yang melibatkan banyak unsur seperti politisi, pengusaha bahkan akademisi melakukan praktek semacam ini. Dalam kontek yang demikian, uang terkonstruksi sebagai dewa penolong dan mantra ampuh yang seolah menjadi satu-satunya instrument fundamental untuk mendapatkan kekuasaan.

Melihat realitas tersebut, politik uang mampu (money politics) sangat jelas memberikan andil dalam menyuburkan benih-benih kebobrokan moral masyarakat. Memang uang merupakan benda mati, namun uang seperti halnya pisau, tergantung siapa dan untuk apa benda tersebut dipakai. Uang bisa memberikan makna positif manakala uang tersebut digunakan untuk kegiatan/aktivitas yang legal dan mempunyai implikasi positif bagi masyarakat (Fagthuri, 2010). Politik uang membuat demokrasi (Faqthuri, 2010). Politik uang membuat demokrasi tidak ubahnya seperti obyek mati yang dimainkan oleh kekuatan politik sesuka hatinya. (El-Manaf, 2008)

Begitupun halnya dengan pisau, akan memberikan makna positif manakala digunakan untuk kegiatan legal dan memberi dampak positif bagi masyarakat atau si pengguna bukan sebaliknya untuk mempermulus niat jahat seperti membunuh dsb. Berangkat dari realitas yang demikian, apa sebetulnya uang itu?

Sebagaimana diuraikan diatas, uang bisa berkonotasi negatif tergantung pada siapa dan untuk apa uang tersebut digunakan. Terkait dengan hal ini, makna uang menurut Macfarlane mempunyai ciri-ciri buruk dimana uang menurutnya sepadan dengan kejahatan atau "money is evil". Mengapa demikian? Uang dalam wujudnya yang demikian menurutnya adalah sumber malapetaka sebab uang mewujud dalam bentuknya yang rakus, konsumerisme dan selalu mencari keberuntungan (profileer). Karakteristik yang disebutkan Macfalane merupakan simbol-simbol yang selalu ada dalam wajah kapitalisme dimana uang membawa dampak positif bagi kehidupan sosial masyarakat. Sebaliknya, uang menjadi sumber ketidakteraturan sosial (social disorder) sehingga sirkulasinya harus dicegah dan dilawan oleh semua orang. (Faqthuri, 2010) 
Tanpa bermaksud mengamini apa yang digambarkan oleh Macfarlane, kenyataan di Indonesia saat inijuga tidak jauh berbeda dengan karakteristik diatas. Uang semakin menampakkan wujudnya yang buruk ketika dimainkan oleh segelintir orang yang tidak bertanggung jawab untuk tujuan-tujuan mencapai kekuasaan. Bagi mereka yang melakukan praktek kotor melalui "money politics", mereka secara tidak langsung telah melakukan kejahatan serta pembodohan terhadap masyarakat (Faqthuri, 2010). Masyarakat yang semestinya sebagai pemegang kedaulatan, akhirnya dikorbankan dalam pembodohan atas nama realitas budaya atau kepentingan temporer. (Faisol, 2009, Munawar, 2009)

Dampak ikutan yang paling mengenaskan dari praktek politik uang adalah suksesnya para elit menularkan kebiasaan buruk tersebut. Dikatakan sukses karena praktek tersebut sudah mewabah di masyarakat sehingga dalam derajat tertentu, masyarakat kita sangat tergantung kepada makhluk uang terutama ketika mereka harus ikut berpartisipasi dalam politik. Lebih tragis lagi masyarkat sampai tidak mau memberikan kalau mereka tidak diberi uang atau bantuan bantuan yang lain. Tengoklah kasus yang menimpa Andi Yuliani Paris, Caleg nomor i Dapil Sulawesi Selatan II PAN. Di salah satu kecamatan di Bone baru-baru ini, kabupaten dari 9 Kabupaten/Kota dapil Sulsel II, Andi mengaku kerap dipalak konstituen sehingga Andi pun mengaku heran dengan perilaku masyarakat pedalaman yang dianggapnya matre tersebut (detik.com (20/1/ 2009). Fenomena yang tak jauh berdeda juga terjadi di Sampang Madura, praktik politik uang pada malam coblosan Pilgub putaran ketiga marak terjadi. (Faqthuri, 2010)

\section{MORALITAS POLITISI INDONESIA}

Jannah (2005) menyebut, praktek politik uang dapat dihindari jika para calon dan masyarakat menyadari sepenuhnya bahwa pilkada harus berjalan sesuai dengan aturan yang berlaku. Masyarakat terlibat secara cerdas dan ikut memantau prsoses pilkada tersebut degan berpatokan pada ketentuan yang berlaku. Oleh karena itu berbagai persoalan politik uang dalam pilkada semuanya dikembalikan kepada masyarakat dan kejujuran para calon yang akan berlaga, disamping penegakan hukum kepada setiap orang yang melakukan pelanggaran dengan tanpa pandang bulu, harus menjadi prioritas utama.

Pemerintahan daerah dalam hal ini, seharusnya melakukan terobosan yang cepat untuk membersihkan Institusi Peradilan, Polisi, Penegak hukum, jaksa, hakim, serta unsur-unsur hukum lainnya dari yang anti perubahan. Hal tersebut di pahami sebagai langkah maju dalam menciptakan kepastian hukum (certainty of law) dan persamaan di hadapan hukum (equality before the law) dapat segera diwujudkan. Penegakan hukum terlhadap berbagai pelanggaran dalam pilkada dipahami sebagai para mapia peradilan dan orang-orang langkah maju dalam menciptakan kepastian hukum (certainty of law) dan persamaan di hadapan hukum (equality before the law) dapat segera diwujudkan. Penegakan hukum terhadap berbagai pelanggaran dalam pilkada dipahami sebagai langkah maju dalam membangun dacrah yang bersih dan berwibawa. Proses penegakan hukum 
ini harus diawali dari kesungguhan Pemerintahan tidak hanya sebatas jargon saja. Sebab pada intinya penegakan hukum adalah persoalan keberanian dan nyali. (Jannah, 2005)

Penegakan hukum disini dilakukan tanpa ada diskriminatif, sehingga penegakan tersebut berlaku untuk semua orang yang melakukan pelanggaran dalam pilkada tanpa ada batas ras, jenis kelamin, suku, kaya dan miskin. Tetapi hukum ditegakk tanpa ada pandang bulu terhadap persoalan stat sosial masyarakat. Dan karena itulah saya ingin mengatakan balhwa penegakan hukum harus seperti dua mata pedang yang sama-sama tajam. Ke atas tajam dan ke bawah pun tajam, tidak seperti penegakan hukum yang menggunakan logika kapak, ke bawah tajam sedangkan ke atas tumpul. (Jannah, 2005)

Jika politik uang terus terjadi, dapat dipastikan bahwa dunia politik akan menjadi semakin rusak Demokrasi prosedural hanya akan menjadi lahan bagi kaum medioker, yaitu mereka yang tidak memiliki prestasi memadai, untuk meraih kekuasaan. Bahkan sangat mungkin demokrasi prosedural akan dimanfaatkan oleh mereka yang memiliki hasrat tak terbendung dan kerakusan untuk menguasai harta kekayaan negara. Karena itu, segala macam cara kemudian mereka lakukan untuk memperoleh kekuasaan. Dan kekuasaan itu nantinya akan digunakan untuk mengembalikan uang yang telah digunakan untuk memperoleh kekuasaan itu. Bahkan ia akan digunakan untuk mendapatkan kekayaan dengan jumlah yang berlipat-lipat. Karena itulah, politik uang harus dianggap sebagai kejahatan besar dalam politik yang harus dilawan dan dienyahkan secara bersamabersama- sama. Kejahatan politik uang tidak boleh dibiarkan tumbuh subur, kecuali masyarakat di negeri ini merelakan demokrasi ikut terkubur. (Fatwa, 2008)

Untuk melawan praktik politik uang, benar-benar diperlukan para politikus sejati yang memahami bahwa pengertian politik adalah seni menata negara dan tujuannya adalah menciptakan kebaikan bersama agar rakyat lebih sejahtera. Politik memerlukan orang-orang baik, memiliki keunggulan komparatif dalam artian memiliki kompetensi, dan sekaligus juga memiliki keunggulan kompetitif. Sebab, kebaikan dalam politik perlu diperjuangkan sampai ia tertransformasi ke dalam kebijakan- kebijakan politik negara. Nilai hanya akan menjadi hidup apabila ia telah teraplikasi ke dalam praktik kehidupan keseharian. Nilai yang tak tertransformasikan, hanya akan berada di menara gading dan awang-awang yang tidak akan memberikan pengaruh nyata kepada kehidupan rakyat banyak. (Fatwa, 2008)

Untuk mengontrol merajalelanya praktik penyelewengan uang dalam dunia politik, harus ada good will dan komitmen semua pihak untuk berusaha keras agar bisa membendung praktek terlarang tersebut. Aturan dengan mengikutsertakan semangat kredibelitas dan akuntabilitas saja tidak cukup, sehingga aspek moral harus ditempatkan di garda terdepan. Moralitas memberi andil yang cukup besar dalam rangka membendung praktek kotor yang kerap muncul dalam dunia politik 
(Fathkuri 2010). Moralitas merupakan tameng yang idealnya mampu mencegah kecenderungan melakukan penyimpangan norma yuridis seperti politik uang.

\section{Kajian Islam}

Demokrasi membuka celah berkuasanya para pemimpin yang peduli dengan rakyat dan sebaliknya bisa melahirkan pemimpin yang buruk. Harapan rakyat akan adanya pemimpin yang peduli di masa demokrasi ini adalah harapan dari implementasi demokrasi itu sendiri. Di masa trans is i ini, implementasi demokrasi masih terbatas pada kebebasan dalam berpolitik, sedangkan masalah ekonomi masilh terpinggirkan. Maka muncul kepincangan dalam kehidupan berbangsa dan bernegara. Politik dan ekonomi adalah dua sisi yang berbeda dalam sekeping mata uang, maka masalah ekonomi pun harus mendapat perhatian yang serius dalam implementasi demokrasi agar terjadi penguatan demokrasi (Prayitno, 2010). Sayangnya, penguatan demokrasi ini menjadi semakin sulit atau jauh dari perwujudannya di Indonesia akibat praktik politik uang yang belum mereda, apalagi tuntas.

Staquf (2009) menyatakan, dimana letak idealisme dalam (demokrasi) politik? Kalau politik itu the art of the possible, berarti "apa yang harus" dari idealisme harus didamaikan dengan "apa yang mungkin" dalam realitas. Proses politik (yang demokratis) membutuhkan pragmatisme yang memadai. "Ada dua perkara di dunia ini yang, kalau orang tahu cara membuatnya, orang tidak doyan", kata Churchill, "yang pertama sosis; yang kedua adalah undang-undang! Pekerjaan menggulirkan proses politik di lingkungan demokrasi meliputi rangkaian aksi: mengancam, membujuk dan menukar. Bahkan tidak jarang untuk tidak mengatakan "hampir selalu", proses itu melibatkan uang. Dan karenanya seringkali tampak menjijikkan oleh kacamata idealisme.

Nabi Muhammad SAW empat belas abad lalu misalnya juga sudah menyampaikan koreksinya kepada masyarakat "baik penyuap maupun yang disuap tempatnya di neraka". Peringatan ini memberi pelajaran, bahwa penyuap maupun yang disuap kedudukannya egaliter, sama-sama melakukan peri laku aib, tidak bermoral, dan membenarkan kontrak mematikan nilai-nilai adiluhung. Dalam doktrin Islam ini, penyuap maupun yang disuap sama-sama melakukan kriminalitas yang tergolong keji.(Ghafar, 2008).

Penyuap itu menggunakan uang, barang, atau lainnya yang kadarnya berharga, yang dinilainya bisa mempengaruhi keyakinan, ideologi, agama, dan ketahanan moral pihak yang disuap. disuap berani juga Sementara yang mempertaruhkan keyakinan, ideologi, agama, dan ketahanan moralnya demi menuai keistimewaan atau dimensi privilitas yang diberikan penyuap.

Logis kalau agama mengutuk perbuatan itu, karena kesucian moral telah digadaikan, dibarterkan, dan dimatikan oleh kedua belah pihak yang menyepakati lahirnya kontrak-kontrak yang lebih memuliakan atau meninggikan kepentingan hedonisme politik, kepuasan biologis, dan arogansi diri di atas nilai-nilai 
kebenaran dan kejujuran. Dalam sisi lain, praktik demikian disebut pula sebagai suap-menyuap.

Sebagai bahan refleksi, dalam sejarah Islam tercatat, Umar bin Abdul Azis dikenal sebagai seorang khalifah yang sangat jujur, tidak pernah mau menerima hadiah dari siapa pun. Sesaat setelah ia dinobatkan datanglah seorang konglomerat yang hendak memberikan hadiah kepadanya. Tapi, khalifah menolak keras pemberian itu. Umar bin Abdul Azis mengartikannya sebagai usaha penyuapan dan penyogokan. (Shalhab, 2008)

Kolusi dan persekongkolan antara pejabat dan pengusaha yang dapat berdampak pada penyuapan, penyogokan, korupsi, dan pemberian katebelece, sangat ditentang keras oleh Islam. Apalagi kalau dilakukan oleh seorang pejabat, ketika dilantik atas nama Allah dia bersumpah untuk tidak menerima hadiah atau sesuatu pemberian yang diketahui atau diperkirakan akan merugikan negara dan jabatannya. Suatu sumpah yang harus dipertanggungjawabkan kepada Allah. Hal ini dijelaskan baik dalam Alquran maupun sunah. Nabi Muhammad SAW bersabda, Orang yang memberikan sogok, yang menerimanya, dan yang menjadi perantaranya, semuanya masuk neraka. (Shahab, 2008)

Khalifah Ali bin Abi Thalib ketika mendapat laporan bahwa gubernurnya di Mesir dijamu makan oleh para pengusaha setempat, dia menjadi khawatir dan memperingatkan, *"Tegakkanlah keadilan dalam pemerintahan dan pada diri Anda sendiri, dan carilah kepuasan rakyat, karena kepuasan rakyat memandulkan kepuasan segelintir orang yang berkedudukan istimewa. Segelintir orang yang berkedudukan istimewa itu tidak akan mendekati Anda ketika Anda dalam kesulitan." Ketika segelintir orang ini sudah dibantu atau dimenangkan, mereka secepatnya melupakan (Shahab, 2008, Wahid, 2010)

Kontrak bermuatan "pembusukan moral" (moral decay), yang kemudian popular disebut money politics, karena salah satu klausulanya yang dinilai dengan uang sebagai kiblat sejatinya, jelas potensial sekali mampu menghambat kehidupan dan pencerahan demokrasi di negara ini, karena masing-masing pelaku sosial-politiknya terseret dalam a pergulatan mendahulukan atau mengutamakan prinsip seperti yang didoktrinkan Nicollo Machiavelli "het doel heiling de middelen" (penghalalan segala cara untuk mencapai tujuan). (Wahid, 2010, Ahmad, 2009)

Di alam demokrasi, yang idealnya disebut suatu konstruksi kehidupan kemasyarakatan dan kenegaraan yang berbasis kerakyatan, tentulah setiap bentuk praktik-praktik politik yang diselenggarakan untuk mencari figur pemimpin, seperti pilkada (pemilihan kepala daerah), tidaklah boleh meninggalkan misi utamanya, bahwa pencerdasan, pencerahan, dan penyehateraan kehidupan rakyat adalah target istimewa yang wajib ditegakkan, dan bukannya target yang lebih dominan memuaskan kepentingan pribadi, kroni, dan partai.

Sayangnya, target istimewa tersebut belum menjadi idealisme yang dihormati oleh setiap pelaku politik di negeri ini. Mereka rupanya masih belum bisa keluar dari belitan obsesi utamanya dalam bentuk memburu kursi dengan 
menghalalkan segala cara dibandingkan tidak dapat kursi dengan predikat sebagai pahlawan penegak nilai-nilai moralitas.

Kemenangan ukuran masihlah "absolut" ditentukan lewat kursi yang diraih dan bukannya dalam tataran mengalahkan segala bentul keinginan besar yang mengejawentah. mengadaptasi, dan mengakomodasi praktik penelanjangan atau pembiaran etika.

Tolok ukur itu berlaku demikian ketat karena besarnya dan tingginya penghargaan seseorang dan komunitas terhadap daya kerja, keampuhan, dan kesakralan uang. Terbukti, begitu money politics berlaku dan berjaya, maka idealisme yuridis dan kemapanan moral keagamaan menjadi runtuh dan lenyap ditelan prahara kejahatan berdimensi kekuasaan yang sedang menempati piramida tertingginya.

Penolakan terhadap money politics itu dapat terlihat dengan seringnya diadakan seminar yang mengkritik dampak money politics. Di Jawa Timur beberapa kali Bahstul Masail yang diselenggarakan NU di daerah-daerah yang menyelenggarakan pilkada langsung juga sudah memutuskan fatwa haram. Tetapi toh, fatwa ini tampaknya sulit diindahkan oleh masyarakat, karena masalah suapmenyuap atau money politics sudah diterima sebagai adat dan kultur.

Dalam dimensi politik yang menurut istilah El-Manaf (2008), sudah sampai ke "supra hegemonik, berat sekali mengidealkan kekuatan religiusitas mampu mengalahkan dan menyingkirkan kepentingan uang, karena paradigma yang digunakan oleh masyarakat telah menempatkan politik sebagai "mesin uang". Dalam tataran demikian, agama tidak lebih hanya sebagai kekuatan simbol yang kehilangan makna karena dikalahkan oleh rezim atau kekuaatan uang yang demikian superior memasuki dan menguasai seseorang atau masyarakat.

Berbagai ayat Alquran dan hadis Nabi SAW menjadi jelas dan tidak disangsikan lagi bahwa Islam mengutuk segala bentuk kolusi, penyuapan, dan sogok-menyogok, mengingat bahayanya bagi masyarakat. Aparat yang 'terbeli' tidak dapat lagi bersikap objektif, sementara rakyat kecil di bidang hukum mendapat perlakuan yang tidak adil. Apabila hal ini dibiarkan akan membahayakan sendi-sendi negara, dan hilanglah kepercayaan rakyat terhadap aparat penegak hukum. (Shahab, 2008)

Sayangnya, di mayoritas masyarakat muslim Indonesia ini, kekuatan praktik suap- menyuap sudah memasuki pori-pori atau jaringan terdalam kehidupan masyarakat terbukti, baik untuk memperjuangkan dan menuai nilainilai kebaikan, keadilan, dan harkat kemanusiaan guna menjinakkan birokrat pemerintahan maupun peradilan, maupun lebih-lebih untuk memenangkan kejahatan, kebatilan, dan keankaran murkaan, apalagi untuk mewujudkan obsesi merebut kekuasaan, yang dalam paradigma kapitalisme sosial dinilai sebagai sumber kemapanan status elitisme ekonomi dan politik. Uang telah terbukti disalahgunakan untuk merusak ideologi dan teologi masyarakat. 


\section{Kesimpulan}

Pesta demokrasi merupakan pesta politik yang menunjukkan kedaulatan rakyat. Pemilihan kepala daerah (Pilkada) seharusnya menjadi tahapan penting dalam kehidupan bermasyarakat dan bernegara, karena dalam Pilkada ini, masyarakt terlibat atau dilibatkan sebagai unsur fundamental yang menentukan berjalannya demokrasi. Demokrasi akan terjaga kesuciannya di tangan penyelenggara Pilkada dan rakyat. Kalau penyelenggaranya tidak menjaga kesucian Pilkada dengan sebaik-baiknya, maka Pilkada tidak lebih hanya sebagai pesta politik yang menghambur- hamburkan uang.

Dalam dimensi tersebut, bukan hanya rakyat (konstituen) yang menentukan citra Pilkada, tetapi siapapun yang mempengaruhi rakyat guna mendapatkan dukungan dari rakyat juga besar pengaruhnya terhadap citra demokrasi. Salah satu penyakit politik dan penyimpangan hukum yang menodai citra pesta demokrasi (Pilkada) adalah politik uang (money politics). Sudah saatnya, setiap anggota masyarakat tidak menggadaikan demokrasi dengan politik uang, karena politik uang hanya akan membuat masa depan negara menjadi makin terpuruk sebagai negara tanpa etika. Rakyat sudah seharusnya punya keberanian berkata "tidak" ketika disalahgunakan untuk merusak ideologi dan teologi masyarakat.

\section{DAFTAR RUJUKAN}

Ahmad, Hamim, 2009, Kehancuran Demokrasi: Duri dalam Membangun Republik, makalah disampaikan dalam diskusi di Yayasan Permata Hati, tanggal 4 Mei 2009.

El-Manaf, Sirozi. 2008. Politik Uang dan Gerakan Pemelamahan Demokrasi, Surabaya: Cahyapres.

Faisol, Moh. 2009. Politik Uang Menghegemoni Demokrasi dan Hukum, makalah disampaikan dalam diskusi di Yayasan Permata Hati, 15 Desember 2009.

Fathkuri, http://www.gp-ansor.org/opini/politik- uang-dan-uang-politik. html, tanggal 15 Maret 2010.

Fatwa, AM. Pelita, 26 November 2008. "Melawan Praktik Politik Uang"

Ghafar, Abdul. 2008. Uang dan Politikus, Yogyakarta: Penyebar Demokrasi http://www.indonesiamenulis.com/2009/05/politik-uang-danmarginalisasi-demokrasi.html

Jannah, Maulana. 2005. Politik Uang dalam Pilkada diakses, dipublikasikan: 18/10/2005 14:35:18

Munawar, Choirul. 2009. Politik Uang, Berhala Kontemporer. Surabaya: Gagasan Indonesia Baru.

Prayitno, Irwan, 2010, Perkembangan Demokrasi di Indonesia, Cabaran dan Pengharapan, www.pas.org.my/kertaskerj a/

Shahab, Alwi, 2008, Sogok, Republika, 6 Maret 2008 
Staquf, Yahya Cholil, Politik Uang, http:// mimbardemokrasi.blogspot.com /2009/04/ politik-uang_07.html.

Wahid, Abdul. 2010, Kearifan Bernegara, Surabaya: Mahirsindo Pustaka.. Perkemhttp: 11, diakses tanggal 15 Maret 2010,

Kabul, Imam, 2007, Dari Langit Menjadi Negarawan, Jakarta: Nirmana Media.

Kansil. CST. 2000. Pengantar Tata Hukum Indonesia dan Pengantar IImu Hukum, Jakarta: Balai Pustaka.

Mubammad, Najib, 2003, Belajar Menjadi Negarawan, Bandung: Humanika

Nur R, Endah, 2009, Menjadi Manusiawi, Republika, 21 Juli 2009.

Santoso, Thomas (Editor), 2002, Teori-Teori Kekerasan, Jakarta: Ghalia Indonesia \& Universitas Kristen Petra.

Santoso, Topo, dkk, 2001, Kriminologi, Jakarta: Rajawali Pers.

Sidharta. Arief, 1993, Percikan Gagasan Tentang Hukum, Bandung: Citra Aditya Bhakti.

Soekanto. Soerjono. 1979. Faktor-faktor yang Mempengaruhi Penegakan Hukum, Jakarta: Rajawali Pres.

Tanuwijaya. Fanny, 2001, Dinamika Hukum, Fakultas Hukum Universitas Islam Malang.

Wahab, Solihin Abdul. 1999. Ekonomi Politik Pembangunan, Bisnis Indonesia Era Orde Baru dan di Tengah Krisi Moneter, Malang: Danar Wijaya.

Wahid, Abdul, 2010, Kearifan Bernegara, Surabaya: Mahirsindopersada. 